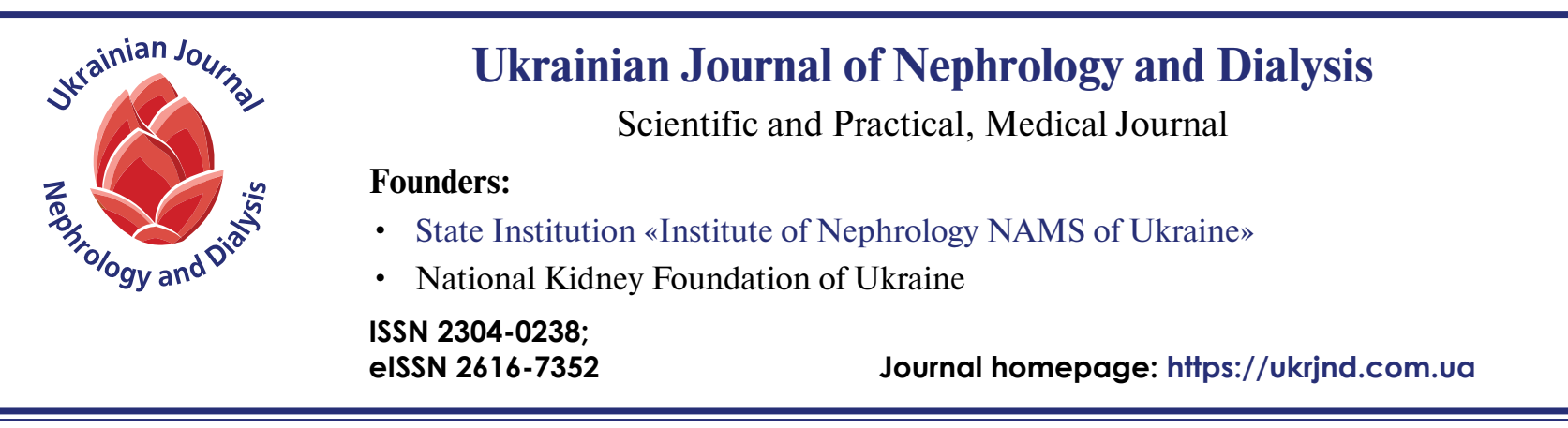

\section{Protocol}

doi: $10.31450 /$ ukrjnd.3(59).2018.01

\section{Snisar, L. Liksunova}

\section{Protocol of chemical and bacteriological safety control of water for hemodialysis / haemodiafiltration}

State Institute «Institute of Nephrology of the National Academy of Medical Sciences», Kyiv, Ukraine

Abstract. Conducting hemodialysis / haemodiafiltration requires the presence of specially prepared water, which is the main component of the dialysing solution. The source of dialysis water is drinking (tap) water which is submitted to purification cascade that involves, among others, pressure driven membranes processes such as reverse osmosis (RO). Proper water treatment is not only a guarantee of the safety of the hemodialysis procedure, but also significantly affects the quality and life expectancy of patients.

Therefore, the chemical and microbiological quality of the water used for dialysis is essential if an additional health risk to haemodialysis patients is to be avoided.

Key words: dialysis water, hemodialysis, chemical quality, microbiological quality, contaminants, reverse osmosis.

Conflict of interest statement: all the authors declared no competing interests.

\section{Article history:}

Received 16 June 2018 Received in revised form 18 July 2018 Accepted 25 July 2018
(C) L. Snisar, L. Liksunova, 2018. All rights reserved Correspondence should be addressed to Lyudmila Snisar: snisarlyudmyla@gmail.com 
УДК:

\author{
Л.М. Снісар, Л.О. Ліксунова
}

\title{
Протокол контролю хімічної та бактеріологічної безпеки води для гемодіалізу/гемодіафільтрації
}

\author{
Державна установа «Інститут нефрології НАМН України», м. Київ
}

Резюме: Проведення гемодіалізу / гемодіафільтрації вимагає наявності спеціально підготовленої води, яка є основним компонентом діалізуючого розчину. Джерелом води для діалізу є питна вода, що подається до каскаду очищення, та включає в себе, зокрема, процеси зворотного осмосу (3О). Належне очищення води є не лише запорукою безпечності процедури гемодіалізу, але й суттєво впливає на якість та тривалість життя пацієнтів.

Контроль хімічної та мікробіологічної якість води, що використовується для діалізу дозволяє уникнути додаткового ризику для пацієнтів, які лікується гемодіалізом / гемодіафільтрацією.

Ключові слова: вода для діалізу, гемодіаліз, хімічна якість, мікробіологічна якість, забруднюючі речовини, зворотний осмос.

\section{А.1 ПАСПОРТНА ЧАСТИНА}

A.1.1 Протокол може бути використаний лікувальними установами, які у своїй структурі мають центр нефрології та діалізу та надають медичну допомогу хворим на XXН V Д ст.

A.1.2 Мета протоколу: стантартизувати контроль хімічної та бактеріологічної безпеки води для гемодіалізу / гемодіафільтрації.

\section{А.1.3 Розробники:}

Снicap Л.М. .м.н., старший науковий співробітник відділу нефрології та діалізу ДУ «Інститут нефрології НАМН України»

Ліксунова Л.О. к.м.н., головний лікар ДУ «Інститут нефрології НАМН України»

\section{А.2 ПРОТОКОЛ КОНТРОЛЮ ХІМІЧНОЇ ТА БАКТЕРІОЛОГІЧНОЇ БЕЗПЕКИ ВОДИ ДЛЯ ГЕМОДІАЛІЗУ / ГЕМОДІАФІЛЬТРАЦІЇ}

\begin{tabular}{|c|c|c|}
\hline Положення протоколу & Обгрунтування & Необхідні дії \\
\hline \multicolumn{3}{|c|}{ І. Профілактика } \\
\hline $\begin{array}{l}\text { Проведення гемодіалізу } \\
\text { вимагає наявності } \\
\text { спеціальним чином } \\
\text { підготованої води, яка є } \\
\text { основним компонентом } \\
\text { діалізуючого розчину. } \\
\text { Належне очищення води є не } \\
\text { лише запорукою безпечності } \\
\text { процедури гемодіалізу, але й } \\
\text { суттєво впливає на якість та } \\
\text { тривалість життя пацієнтів. }\end{array}$ & $\begin{array}{l}\text { Первинна профілактика: } \\
\text { для проведення гемодіалізу } \\
\text { повинна використовуватися } \\
\text { очищена вода, яка як } \\
\text { мінімум, відповідає } \\
\text { європейським стандартам } \\
\text { якості води для гемодіалізу. } \\
\text { Вторинна профілактика: } \\
\text { контроль якості води для } \\
\text { гемодіалізцу відповідно } \\
\text { стандартів. }\end{array}$ & $\begin{array}{l}\text { Обов’язкові: } \\
\text { 1. Наявність системи водопідготовки. } \\
\text { 2. Наявність планового контролю якості } \\
\text { води відповідно протоколу. } \\
\text { 3. Наявність форми контролю результатів } \\
\text { у кожному діалізному центрі. } \\
\text { 4. Проведення регламентних робіт } \\
\text { відповідно рекомендацій виробника. } \\
\text { 5. Наявність алгоритму дій у разі } \\
\text { встановлення невідповідності } \\
\text { якості води для діалізу зазначеним } \\
\text { стандартам. }\end{array}$ \\
\hline
\end{tabular}

\author{
Снісар Людмила Миколаївна \\ snisarlyudmyla@gmail.com
}




\section{II. Діагностика}

Об'єм контролю якості води визначається цим протоколом та здійснюється в центрі нефрології та діалізу.

\section{III. Лікування}

Контроль якості води здійснюється відповідно до протоколу. У разі виникнення погіршення якості водопровідної води, розгерметизації системи відведення води від системи водоочищення та у разі заміни одного з компонентів системи очищення води, контроль якості води проводиться позачергово.
Докази свідчать, що своєчасний та адекватний моніторинг якості води зменшує кількість ускладнень та збільшує тривалість і якість життя у хворих на XXН V Д.
Обов'язкові:

1. Система водопідготовки повинна складатись з блоку попереднього очищення та блоку зворотного осмосу (30).

2. Система водопідготовки може містити ємкості для зберігання очищеної води.

3. Система відводу води від блоку очищення до діалізних апаратів має бути виконана з матеріалу, який попереджує бактеріальну контамінацію та дозволяє проводити дезінфекцію.
Своєчасний контроль та моніторинг якості води для гемодіалізу забезпечує більшу тривалість та кращу якість життя.

Таблиия 1

Максимально допустимі концентрації хімічних елементів у воді для діалізу та частота їх дослідження

\begin{tabular}{|l|c|c|}
\hline \multicolumn{1}{|c|}{ Контамінант } & Мах. концентрація (мг/л) & Частота досліджень* $^{*}$ \\
\hline Токсичні контамінанти & 0,01 & $1 \mathrm{p} / \mathrm{piK}$ \\
\hline Алюміній & 0,1 & Щоденно \\
\hline Загальний хлор & 0,1 & $1 \mathrm{p} / \mathrm{piK}$ \\
\hline Мідь & 0,2 & $1 \mathrm{p} / \mathrm{piK}$ \\
\hline Фторид & 0,005 & $1 \mathrm{p} / \mathrm{piK}$ \\
\hline Свинець & 2 & $1 \mathrm{p} / \mathrm{piK}$ \\
\hline Нітрати (азот) & 100 & $1 \mathrm{p} / \mathrm{piK}$ \\
\hline Сульфати & 0,1 & $1 \mathrm{p} / \mathrm{piK}$ \\
\hline Цинк & & \\
\hline
\end{tabular}


Продовження таблииі 1

\begin{tabular}{|c|c|c|}
\hline Контамінант & Мах. концентрація (мг/л) & Частота досліджень* \\
\hline \multicolumn{3}{|l|}{ Електроліти } \\
\hline Кальцій & 2 (0,05 ммоль/л) & Шоденно \\
\hline Магній & 4 (0,15 ммоль/л) & Щоденно \\
\hline Калій & 8 (0,2 ммоль/л) & Щоденно \\
\hline Натрій & 70 (3,0 ммоль/л) & Щоденно \\
\hline \multicolumn{3}{|c|}{ Хімічні елементи з низькою концентрацією } \\
\hline Сурма & 0,006 & $1 \mathrm{p} / \mathrm{piK}$ \\
\hline Миш'як & 0,005 & $1 \mathrm{p} / \mathrm{piK}$ \\
\hline Барій & 0,1 & $1 \mathrm{p} / \mathrm{piK}$ \\
\hline Берилій & 0,0004 & $1 \mathrm{p} / \mathrm{piK}$ \\
\hline Кадмій & 0,001 & $1 \mathrm{p} / \mathrm{piK}$ \\
\hline Хром & 0,014 & $1 \mathrm{p} / \mathrm{piK}$ \\
\hline Ртуть & 0,0002 & $1 \mathrm{p} / \mathrm{piK}$ \\
\hline Селен & 0,09 & $1 \mathrm{p} / \mathrm{piK}$ \\
\hline Срібло & 0,005 & $1 \mathrm{p} / \mathrm{piK}$ \\
\hline Талій & 0,002 & $1 \mathrm{p} / \mathrm{piK}$ \\
\hline
\end{tabular}

*- Після початку експлуатації системи водопідготовки, після ремонтних та щорічних регламентних робіт контроль виконується щомісяця впродовж 3-х міс.

Таблиця 2

Рівні мікробіологічної чистоти води для ГД/ГДФ

\begin{tabular}{|l|c|c|}
\hline \multicolumn{1}{|c|}{ Показник чистоти } & \multicolumn{2}{c|}{ Свропейська Фармакопея } \\
\cline { 2 - 3 } & Очищена вода & Ультрачиста вода \\
\hline Мікробна контамінація (колоній утворюючих одиниць/мл) & $<100$ & $<0,1$ \\
\hline Бактеріальні ендотоксини (міжнародних одиниць/мл) & $<0,25$ & $<0,03$ \\
\hline
\end{tabular}

\section{ДОДАТОК 1}

\section{Правила відбору проб води для лабораторних досліджень.}

Відбір виконується з дотриманням правил відбору, зберігання і транспортування.

Посуд для відбору проби має бути чистим і забезпечувати зберігання складу і властивостей відібраної проби при транспортуванні.

Головні вимоги до посуду:

- використовують скляний або поліетиленовий посуд ємністю 1-1,5 л (для розширеного аналізу до 3 л)

- посуд та кришки попередньо ретельно миють, бажано в гарячому мильному розчині (пральні порошки та хромову суміш не можна використовувати!) і багаторазово ополіскують чистою теплою водою

- для мікробіологічного аналізу використовують тільки стерильний посуд, а відбір проби проводять в стерильних рукавичках, або продезінфікованими руками.

- перед відбором проби посуд ополіскують не менше трьох раз тією ж водою, з якої береться проба

- посуд, після відбору проби, має бути промаркований етикеткою, де слід вказати хто замовник, місце відбору, дата і час відбору, кількість і додаткові записи.

Загальні вимоги до відбору проб води, зберігання і транспортування.

1. 3 кранів забір води здійснюють після вільного випуску води при повному відкритті крану впродовж 60 сек. (вода повинна повільно стікати по стінках ємності).

2. При відборі проби з одного і тогож місця забору для різних аналізів першими відбирають проби для мікробіологічного аналізу.

3. Для отримання достовірних результатів аналіз води слід виконувати, по можливості, якнайшвидше, бажано до 6 годин після забору проби. Якщо в день забору проби аналіз не можливо виконати, то проби води рекомендується зберігати в холодильнику не більше 48 годин.

4. Залежно від передбачуваної тривалості зберігання відібраних проб може виникнути необхідність в їх консервації.

5. Для транспортування бажано охолодити проби до температури 2-5 С. Під час транспортуванні ємкості $з$ пробою мають бути захищені від забруднення, ушкодження та самовільного відкриття пробок. 


\section{Алгоритм хімічного контролю води для ГД/ГДФ;}

виконавець - технік

\begin{tabular}{|c|c|c|}
\hline Крок 1. & \multicolumn{2}{|r|}{$\begin{array}{l}\text { Відбір зразків води. } \\
\text { Примітка 1. Проводиться перед дезінфекцією шафи } 30 \text { та дистального сегменту петлі. } \\
\text { Примітка 2. Проводиться відповідно дод. } 1\end{array}$} \\
\hline 1.1 & & $\begin{array}{l}\text { Перший зразок води повинен бути відібраний перед першим фільтром очистки } \\
\text { води (водопровідна вода). }\end{array}$ \\
\hline 1.2 & & $\begin{array}{l}\text { Другий зразок води повинен бути відібраний з дистального сегменту петлі, } \\
\text { безпосередньо перед тим, як вода повертається до } 30 \text {, або безпосередньо перед } \\
\text { тим, як вода повторно надходить у резервуар для зберігання, якщо такий є. }\end{array}$ \\
\hline Крок 2. & \multicolumn{2}{|r|}{ Направлення зразків води до лабораторії та реєстрація у журналі отриманих результатів* } \\
\hline 2.1 & \multicolumn{2}{|c|}{ Оцінка результатів } \\
\hline 2.2 & \multicolumn{2}{|r|}{$\begin{array}{l}\text { Жодна з хімічних складових не перевищує допустимих меж концентрації - виконується } \\
\text { тестування відповідно таб. } 1 .\end{array}$} \\
\hline 2.3 & \multicolumn{2}{|r|}{$\begin{array}{l}\text { У разі перевищення допустимих меж концентрації хімічних складових виконуються } \\
\text { коригувальні заходи (перейдіть до кроку 3). }\end{array}$} \\
\hline Крок 3. & \multicolumn{2}{|c|}{ Корекція встановлених порушень } \\
\hline 3.1 & \multicolumn{2}{|r|}{$\begin{array}{l}\text { Концентрація хімічних речовин перевищена в 1-му зразку, повторіть його негайно } \\
\text { (повторіть кроки 1.1-3.1) }\end{array}$} \\
\hline \multirow[t]{5}{*}{3.2} & \multicolumn{2}{|r|}{ Концентрація хімічних речовин перевищена в 2-му зразку (або в обох) : } \\
\hline & 3.2 .1 & $\begin{array}{l}\text { Зібрати та перевірити зразки з інших частин петлі (після пом’якшувача, після } \\
\text { зворотного осмосу, на вході у водогін, на вході до діалізного апарату). } \\
\text { • Оцінка / корекція методики забору зразків. } \\
\text { • Оцінка / правильне дотримання процедур дезінфекції. } \\
\text { • Оцінка / корегування компонентів системи води. }\end{array}$ \\
\hline & 3.2 .2 & $\begin{array}{l}\text { Якщо необхідно, вимкніть шафу 30, зареєструйте подію в протоколі, зверніться до } \\
\text { служби сервісу. }\end{array}$ \\
\hline & 3.2 .3 & Повідомте про це завідувача відділення та чергового нефролога. \\
\hline & 3.2 .4 & Перезапустіть систему водопідготовки (повторіть кроки з 1 до 3.1). \\
\hline
\end{tabular}

* Всі результати хімічних аналізів води для ГД/ГДФ, які отримані з лабораторії, повинні бути задокументовані техніком в журналі. У разі наявності порушень, черговий нефролог доповідає завідувачу відділення. Завідувач відділення підписує та аналізує отримані результати.

\section{Алгоритм мікробіологічного контролю води для ГД/ГДФ}

\begin{tabular}{|l|l|}
\hline Крок 1. & $\begin{array}{l}\text { Відбір зразків води. } \\
\text { Примітка: Зразки слід завжди відбирати перед дезінфекцією шафи 3О та дистального } \\
\text { сегменту петлі. }\end{array}$ \\
\hline 1.1 & $\begin{array}{l}\text { Перший зразок води повинен бути відібраний перед першим фільтром очистки води } \\
\text { (водопровідна вода). }\end{array}$ \\
\hline 1.2 & $\begin{array}{l}\text { Другий зразок води повинен бути відібраний з дистального сегменту петлі, безпосередньо } \\
\text { перед тим, як вода повертається до 3О, або безпосередньо перед тим, як вода повторно } \\
\text { надходить у резервуар для зберігання, якщо такий є. }\end{array}$ \\
\hline 1.3 & $\begin{array}{l}\text { Зразки відбираються після вільного випуску води при повному відкритті крану впродовж } \\
\text { 60 сек. }\end{array}$ \\
\hline 1.4 & Кранів не слід дезінфікувати. \\
\hline 1.6 & $\begin{array}{l}\text { Кількість води, яка необхідна для мікробіологічного аналізу, визначається лабораторією, } \\
\text { що проводить аналіз. }\end{array}$ \\
\hline & На ємкості зазначається місце, дата, час забору води. \\
\hline
\end{tabular}


Продовження таблиці

\begin{tabular}{|c|c|c|}
\hline Крок 2. & \multicolumn{2}{|c|}{$\begin{array}{l}\text { Направлення зразків води в мікробіологічну лабораторію та реєстрація у журналі } \\
\text { отриманих результатів* }\end{array}$} \\
\hline 2.1 & \multicolumn{2}{|c|}{ Оцінка отриманих результатів. } \\
\hline 2.2 & \multicolumn{2}{|c|}{$\begin{array}{l}\text { Мікробна контамінація не перевищує рівня } 50 \text { КУО/мл - виконується мікробіологічне } \\
\text { дослідження 1р/міс. відповідно таб. 2. (після установки системи, ремонтних та щорічних } \\
\text { регламентних робіт щотижня впродовж } 1 \text { місяця). }\end{array}$} \\
\hline 2.3 & \multicolumn{2}{|c|}{$\begin{array}{l}\text { У разі перевищення допустимих меж мікробної контамінації виконуються коригувальні } \\
\text { заходи (перейдіть до кроку 3). }\end{array}$} \\
\hline Крок 3. & \multicolumn{2}{|c|}{ Корекція встановлених порушень } \\
\hline 3.1 & \multicolumn{2}{|c|}{ Кількість КУО перевищена в 1-му зразку, повторіть його негайно (повторіть кроки 1.1-3.1) } \\
\hline \multirow[t]{4}{*}{3.2} & \multicolumn{2}{|c|}{ Кількість КУО перевищена в 2-му зразку (або в обох) : } \\
\hline & 3.2 .1 & $\begin{array}{l}\text { Мікробна контамінація перевищує } 100 \text { КУО/мл, організовуйте екстрену } \\
\text { дезінфекцію (впродовж } 24 \text { годин), використовуючи оцтову кислоту та } \\
\text { повідомте про це завідувача відділення та чергового нефролога. Зареєструйте } \\
\text { подію у відповідному протоколі. }\end{array}$ \\
\hline & 3.2 .2 & $\begin{array}{l}\text { Зібрати та перевірити зразки з інших частин петлі (після пом’якшувача, після } \\
\text { зворотного осмосу, на вході у водогін, на вході до діалізного апарату, на виході } \\
\text { запарату). } \\
\text { • Оцінка / корекція методики забору зразків. } \\
\text { • Оцінка / правильне дотримання процедур дезінфекції. } \\
\text { • Оцінка / корегування компонентів системи води. } \\
\text { • Оцінка мікробіологічних даних за попередні } 3 \text { місяці }\end{array}$ \\
\hline & 3.2 .3 & Повторіть кроки з 1 до 3.1. \\
\hline
\end{tabular}

Журнал отриманих результатів

\begin{tabular}{|c|c|c|c|c|c|c|c|c|}
\hline \multicolumn{4}{|l|}{ Збір даних / щоденний звіт } & \multicolumn{5}{|c|}{$\begin{array}{l}\text { Рік: } \\
\text { Календарний тиждень: }\end{array}$} \\
\hline День тижня & $\Pi_{\mathrm{H}}$ & Bт & $\mathrm{Cp}$ & $\mathrm{U}_{\mathrm{T}}$ & $\Pi_{\mathrm{T}}$ & Сб & Нд & \\
\hline \multicolumn{9}{|l|}{ Час } \\
\hline & \multicolumn{7}{|c|}{ Записи (технік) } & Одиниці \\
\hline Кондуктивність перміату & & & & & & & & $\mathrm{MKCM} / \mathrm{cm}$ \\
\hline Температура перміату & & & & & & & & ${ }^{\circ} \mathrm{C}$ \\
\hline Калій & & & & & & & & ммоль/л \\
\hline Магній & & & & & & & & ммоль/л \\
\hline Кальцій & & & & & & & & ммоль/л \\
\hline Натрій & & & & & & & & ммоль/л \\
\hline $\begin{array}{l}\text { Підпис } \\
\text { Технік: } \\
\text { Черговий нефролог: }\end{array}$ & & & & & & & & \\
\hline
\end{tabular}

\begin{tabular}{|c|c|c|c|c|c|c|c|c|c|c|c|c|c|}
\hline \multicolumn{4}{|c|}{ Збір даних / щомісячний звіт } & \multicolumn{3}{|c|}{$\begin{array}{l}\text { Piк: } \\
\text { Мiсяць: }\end{array}$} & \multirow[b]{2}{*}{ VII } & \multirow[b]{2}{*}{ VIII } & \multirow[b]{2}{*}{ IX } & \multirow[b]{2}{*}{$X$} & \multirow[b]{2}{*}{ XI } & \multirow[b]{2}{*}{ XII } & \multirow[b]{3}{*}{ Одиниці } \\
\hline Місяць & $\mathrm{I}$ & II & III & IV & $\mathrm{V}$ & $\mathrm{VI}$ & & & & & & & \\
\hline & \multicolumn{12}{|c|}{ Записи (технік) } & \\
\hline $\begin{array}{l}\text { Мікробна } \\
\text { контамінація }\end{array}$ & & & & & & & & & & & & & КУО/мЛ \\
\hline $\begin{array}{l}\text { Бактеріальні } \\
\text { ендотоксини }\end{array}$ & & & & & & & & & & & & & МО/мл \\
\hline $\begin{array}{l}\text { Підпис: } \\
\text { Технік } \\
\text { Зав. від. }\end{array}$ & & & & & & & & & & & & & \\
\hline
\end{tabular}




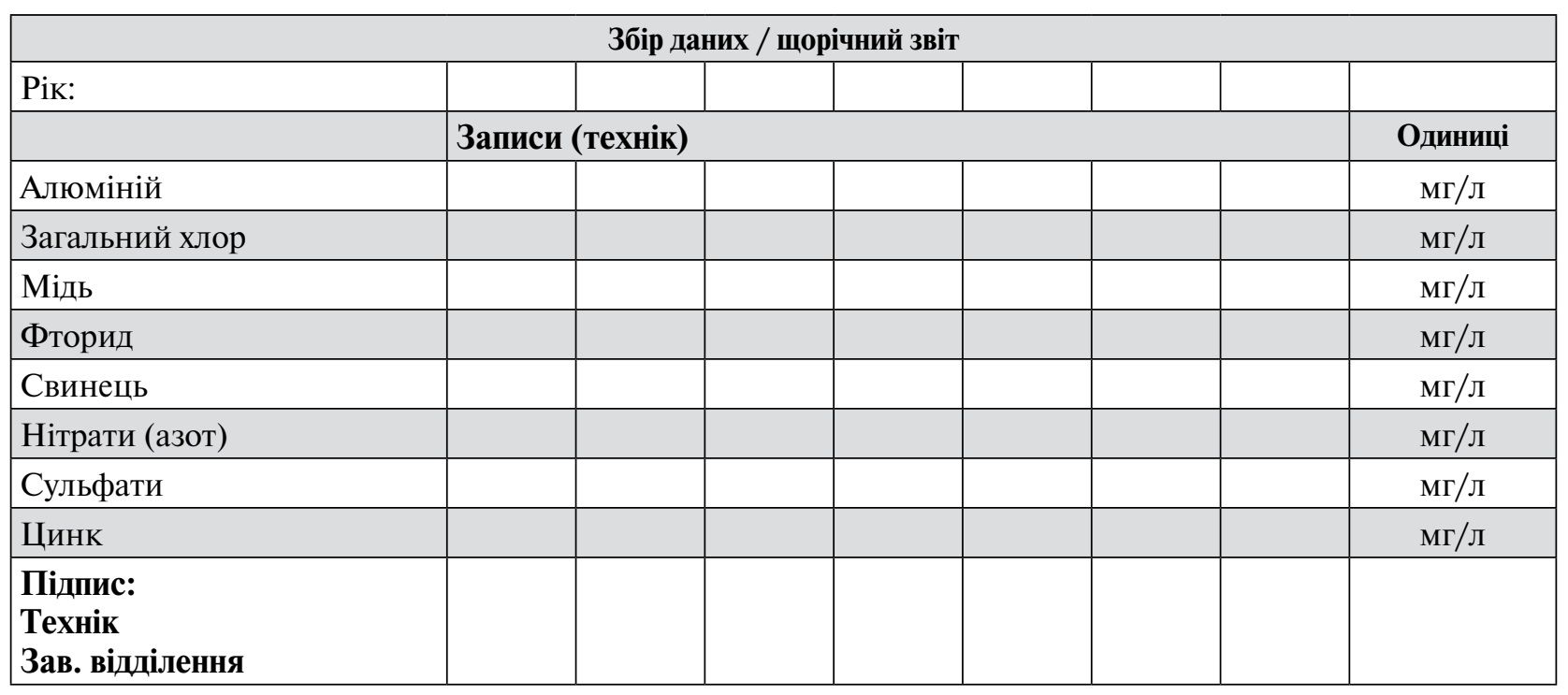

\section{Лiтература (References):}

1. Kolesnyk M, Dudar I, Stepanova N, Gonchar Y, Shifris I, Loboda O. Adaptovana klinichna nastanova, sasnovana na dokasah ta unifikovani klinichni protocol. Licuvannia hvoryh na hronichnu hvorobu nyrok V GD stadii: 2016 rik. Kyiv; 2016. 228 p. [In Ukrainian].

2. Water for haemodialysis and related therapies. CAN/CSA-ISO 13959-11. Canadian Standards Association; 2011. Available from: http://www. bcrenalagency.ca

3. Dialysate for hemodialysis. ANSI/AAMI RD52:2004/(R)2010, Association for the Advancement for Medical Instrumentation, Arlington (VA); 2009. 54 p. Available from: http:// www.therenalnetwork.org/home/resources/CfC/ AAMI_RD520408.pdf

4. Water for haemodialysis and related therapies. BS EN ISO 13959; 2015. 16 p. Available from: https:// shop.bsigroup.com/ProductDetail

5. Concentrates for haemodialysis and related therapies. BS EN ISO 13958:2015. Available from: www.iso.org

6. Quality of dialysis fluid for haemodialysis and related therapies. BS EN ISO 11663: 2015. Available from: www.iso.org

7. Water treatment equipment for haemodialysis and related therapies. BS EN ISO 26722: 2015. Available from: www.iso.org

8. Guidance for the preparation and quality management of fluids for haemodialysis. BS EN ISO 23500: 2015. Available from: www.iso.org

9. Uhlig K, MacLeod A, Craig J. Grading evidence and recommendations for clinical practice guidelines in nephrology. A position statement from Kidney Disease: Improving Global Outcomes (KDIGO). Kidney Int. 2006; 70: 2058-65.
10. Atkins D, Best D, Briss PA. GRADE Working Group. Grading quality of evidence and strength of recommendations. BMJ. 2004;328:1490.

11. Water Quality Standard. ANSI/AAMI 13959:2014. Available from: www.iso.org

12. Levy J, Morgan J. Oxford Handbook of Dialysis. Oxford, Oxford University Press. 2004. Available from: https://www.amazon.com/OxfordHandbook-Dialysis-Medical-Handbooks / $\mathrm{dp} / 0199235287$

13. Poli D, Pavone L, Tansinda P. Organic contamination in dialysis water: trichloroethylene as a model compound. Nephrol. Dial. Transplant. 2006; 21(6): 1618-25. doi.org/10.1093/ndt/gfl036

14. Tattersall J, Martin-Malo A, Pedrini L, Basci A, Canaud B, Fouque D, Haage P, Konner $K$, Kooman $J$, et al. EBPG guideline on dialysis strategies, Nephrology Dialysis Transplantation. 2007;22(2):ii5-ii21. doi: 10.1093/ndt/gfm022

15. Kooman J, Basci A, Pizzarelli F, Canaud B, Haage $P$, Fouque D, Konner K, Martin-Malo A, Pedrini $L$, Tattersall J, et al. EBPG guideline on haemodynamic instability / Nephrol. Dial. Transplant. 2007; 22(2):ii22-44.

16. Cornelis T, Menno P, Kooistra Jeroen Kooman Karel M, Leunissen Christopher T, Chan Frank M. Education of ESRD patients on dialysis modality selection: 'intensive haemodialysis first'. Nephrol. Dial. Transplant. 2010; 25(9): 3129-30. doi: $10.1093 /$ ndt/gfq365 